\title{
Rotator Cuff Repair in the Pediatric Population Displays Favorable Outcomes: A Systematic Review
}

\author{
Nolan B. Condron, B.S., Joshua T. Kaiser, B.S., Dhanur Damodar, M.D., \\ Kyle R. Wagner, B.S., Aghogho Evuarherhe Jr., B.S., Theo Farley, M.Sc., and \\ Brian J. Cole, M.D., M.B.A.
}

\begin{abstract}
Purpose: To systematically review the literature to determine the injury mechanisms, presentation, and timing of diagnosis for pediatric patients with intratendinous rotator cuff tears and to determine the efficacy of surgical intervention for affected patients. Methods: PubMed, Cumulative Index to Nursing and Allied Health Literature (CINAHL), and Scopus were searched. Studies were included if they involved only pediatric patients, soft-tissue rotator cuff injuries managed surgically, and reported outcomes. Patient characteristics, injury mechanisms, physical examination and imaging findings, time to diagnosis, surgical technique, and treatment outcomes were extracted. Findings were descriptively analyzed with weighted means and proportions. Results: Twenty-one studies comprising 78 patients were included. The age range was 8 to 17 years and 57 were male. The supraspinatus $(n=56)$ was the most injured tendon. American football was the most reported sport played at the time of injury. Most patients were diagnosed within 6 months of injury via magnetic resonance imaging. Arthroscopic management was undertaken in 68 patients. Forty-six of 51 patients for whom data were available returned to sports at a range of 2.5 to 12 months postoperatively. Repair failure occurred in three patients. Conclusions: The extant literature regarding rotator cuff tears in pediatric patients is limited to reports of low methodological quality. Qualitative synthesis of this low-level literature reveals that rotator cuff tears are mostly reported in male collision sport athletes but may also occur in female athletes and/or throwing athletes. These injuries are often successfully managed via arthroscopic repair, and patients and their families can be reassured that the majority of patients return to sports following surgery. Level of Evidence: Level IV, systematic review of level IV studies.
\end{abstract}

\section{Introduction}

$\mathbf{R}$ otator cuff tears (RCTs) are common in the general population; however the majority of these

Midwest Orthopaedics at Rush University Medical Center, Chicago, Illinois, U.S.A. (N.B.C., J.T.K., D.D., K.R.W., A.E., B.J.C.); University of Massachusetts Medical School, Worcester, Massachusetts, U.S.A. (N.B.C.); University College London, London, United Kingdom (N.B.C., T.F.); and Institute of Sport, Exercise and Health, London, United Kingdom (T.F.).

The authors report the following potential conflicts of interest or sources of funding: B.J.C. reports being a paid consultant for Arthrex and Regentis; he has received research support from Aesculap, Arthrex, and Regentis; he has received other financial or material support from Athletico, JRF, and Smith $\theta$ Nephew; he holds stock in Ossio and Regentis; and he receives royalties from Arthrex. Full ICMJE author disclosure forms are available for this article online, as supplementary material.

Received September 13, 2021; accepted November 17, 2021.

Address correspondence to Brian J. Cole, M.D., M.B.A., Cartilage Restoration Center at Rush, Rush University Medical Center, 1611 W. Harrison, Suite 300,Chicago, IL 60612,U.S.A.E-mail:bcole@rushortho.com

(C) 2021 THE AUTHORS. Published by Elsevier Inc. on behalf of the Arthroscopy Association of North America. This is an open access article under the CC BY-NC-ND license (http://creativecommons.org/licenses/by-nc-nd/4.0/).

2666-061X/211313

https://doi.org/10.1016/j.asmr.2021.11.010 tears occur as the result of degenerative changes associated with aging. ${ }^{1}$ Up to $80 \%$ of individuals over the age of 80 likely have some degree of degenerative rotator cuff damage. ${ }^{2}$ Traumatic RCTs typically afflict relatively younger patients and are less common, though welldocumented in the literature. ${ }^{3}$ Still, patients with traumatic RCTs usually are in the sixth decade of life. ${ }^{4}$ Meanwhile, in studies performed in the 1980s and 1990s, pediatric RCTs were found to account for less than $1 \%$ of all RCTs. ${ }^{5,6}$ As such, rotator cuff injuries are widely viewed as a pathology of the adult population.

The low incidence of RCTs in pediatric patients is attributed to the anatomy and physiology of the developing musculoskeletal system. Developing osseous structures are susceptible to traumatic and repetitive-use injuries as they undergo maturation because they are the "weakest link" along the musculoskeletal unit. Given this, conditions, such as apophysitis, epiphysiolysis, or avulsion fractures, in which repetitive use of a tendon causes a piece of bone to pull off its insertion, are much more prevalent than intrasubstance tendinous injuries. ${ }^{7}$ The proximal humeral physis typically closes between the ages of 14 and 16 in 
females and 16 and 18 in males. As such, proximal humeral epiphysiolysis, also known as "little leaguer's shoulder," is a common condition in competitive young throwing athletes, who repetitively stress this developing area during training and competition. ${ }^{8}$ During the deceleration phase of throwing, opposing forces of forward arm motion and rotator cuff firing result in excessive eccentric physeal stress. Despite these anatomical differences in younger patients, the rise of early sport specialization and year-round training regimens ${ }^{9,10}$ have led to RCTs being increasingly found in skeletally immature patients. ${ }^{11-13}$

While rotator cuff avulsion fracture injuries are similarly rare in pediatric patients, the incidence of these injuries have been studied, and the outcomes found to be excellent when appropriately diagnosed and managed. ${ }^{14}$ Additionally, avulsion-type injuries are less likely to go undiagnosed as they may be more apparent on plain radiographs given their osseous nature.

On the other hand, no systematic investigation into the incidence, diagnosis, treatment, and outcomes of true tendinous RCTs in pediatric patients has been performed.

Recognition and study of the causes and treatments of RCTs in pediatric patients is necessary in order to accurately evaluate and counsel young patients (and their parents/guardians) who present with significant shoulder pain and functional impairment, particularly following traumatic injury. ${ }^{15}$ Although RCTs are rare in young patients, they must be on the clinician's list of differential diagnoses. Given that tendon tears are less likely to be seen on plain radiographs, clinicians must maintain a high index of suspicion for RCTs, particularly when patients are unresponsive to standard conservative treatment measures. If untreated, RCTs have the potential for significant long-term functional impairment, time away from sport, and resultant psychological distress. ${ }^{16,17}$

The purpose of this study was to systematically review the literature to determine the injury mechanisms, presentation, and timing of diagnosis for pediatric patients with intra-tendinous rotator cuff tears and to determine the efficacy of surgical intervention for affected patients. It was hypothesized that fewer than 100 total cases would be reported in the published literature, with most of these cases occurring as a result of trauma in young contact athletes and that diagnosis would typically be delayed following injury. Further, it was hypothesized that functional and return-to-sport outcomes would be excellent in this population regardless of injury mechanism, involved tendons, and timing or technique of surgical repair.

\section{Methods}

\section{Search Strategy}

This systematic review was performed in accordance with the Preferred Reporting Items for Systematic
Reviews and Meta-Analyses (PRISMA) statement and the methodology proposed by Harris et al. for systematic reviews relating to sports medicine and orthopaedic surgery. ${ }^{18}$ Initial database searches were performed in March 2021, and the investigation was registered on the PROSPERO international prospective register of systematic reviews (PROSPERO ID: CRD42021262649). Three databases were searched: PubMed, Cumulative Index to Nursing and Allied Health Literature (CINAHL), and Scopus. The full search strings used for each database are available in Appendix Table 1. Searches included terms relating to rotator cuff injuries combined with terms relating to pediatric populations using Boolean operators. No limits were set on dates of publication, and only English language publications were considered.

\section{Study Selection and Data Extraction}

This review investigated all studies meeting the following inclusion criteria: 1) clinical studies of human subjects regardless of level of evidence (LOE); 2) included subjects were under 18 years of age; 3) subjects had a diagnosis of rotator cuff tendon tear, regardless of concomitant pathology; 4) subjects were treated with operative management; and 5) subjects had documentation of any reported outcome at any period of follow up. Review articles, conference abstracts, nonhuman studies, biomechanical studies, studies investigating obstetric upper extremity birth trauma, studies with subjects aged 18 years and older,

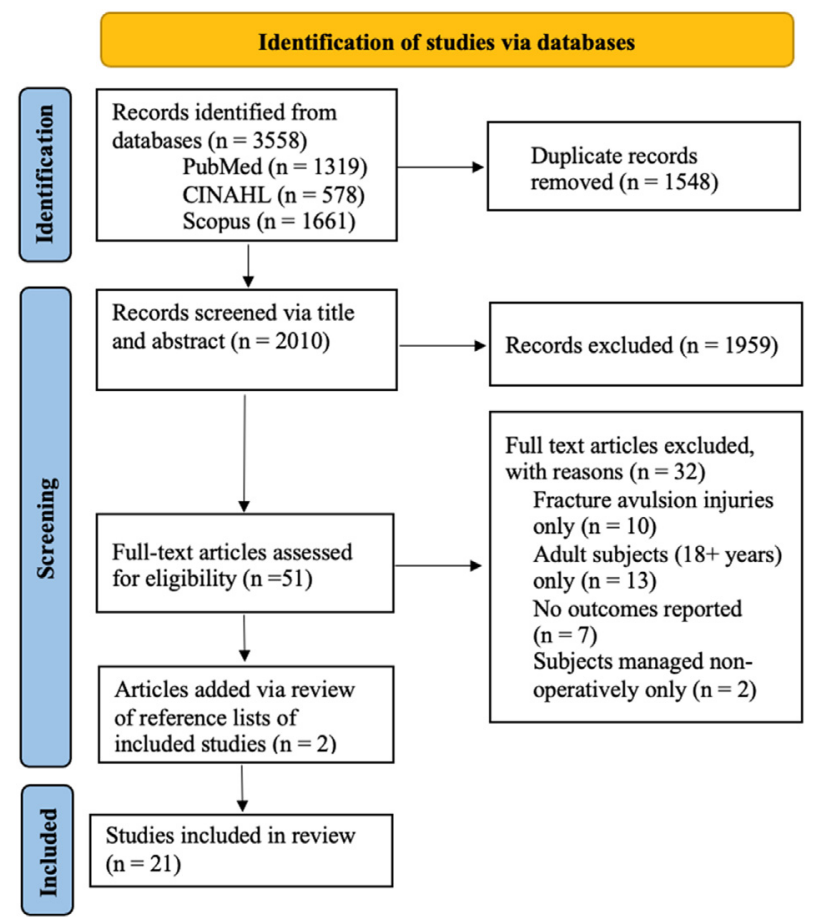

Fig 1. Flowchart of study screening and selection in accordance with the Preferred Reporting Items for Systematic Reviews and Meta-Analysis statement. 
Table 1. Study Level of Evidence, Patient and Injury Characteristics

\begin{tabular}{|c|c|c|c|c|c|c|c|}
\hline Study & LOE & $\begin{array}{c}\text { Patients, } n \text {, } \\
\text { (Male, } n)\end{array}$ & $\begin{array}{l}\text { Average } \\
\text { Age (SD) }\end{array}$ & $\begin{array}{l}\text { RC Tendon(s) } \\
\text { Involved }\end{array}$ & Type of Tear & $\begin{array}{c}\text { Mechanism } \\
\text { (Traumatic or } \\
\text { Nontraumatic) }\end{array}$ & $\begin{array}{l}\text { Inciting Event Sport/ } \\
\text { Activity (Baseline } \\
\text { Sports Competition) }\end{array}$ \\
\hline Agarwalla et al., $2020^{21}$ & $\overline{\mathrm{IV}}$ & $1(1)$ & 15 & SSC & Full thickness & $\mathrm{T}$ & American football \\
\hline Azzam et al., $2018^{23}$ & IV & $24^{\mathrm{a}}(21)$ & $16.1(1.3)$ & $\begin{array}{l}\text { SSP (20); SSC and } \\
\text { SSP (1), SSP and } \\
\text { IS (1), IS (1), } \\
\text { SSP, IS, and TM (1) }\end{array}$ & $\begin{array}{l}\text { Full thickness (4), } \\
\text { partial thickness }(20)\end{array}$ & $\mathrm{T}(22), \mathrm{NT}(2)$ & $\begin{array}{l}\text { Traumatic: American } \\
\text { football (10), baseball } \\
\text { (2), motocross (2), } \\
\text { wrestling (2), } \\
\text { basketball (2), bull } \\
\text { riding (1), motor } \\
\text { vehicle crash (1), } \\
\text { skateboarding (1), } \\
\text { weightlifting (1) } \\
\text { Nontraumatic: } \\
\text { baseball (1), } \\
\text { softball (1) }\end{array}$ \\
\hline Burns et al., $2009^{27}$ & IV & $2(0)$ & $14.5(.71)$ & $\operatorname{SSP}(1), \operatorname{SSP}$ and IS (1) & Full thickness (2) & NT & Softball \\
\hline Eisner et al., $2013^{28}$ & III & $30^{c}(16)$ & $15.5(1.8)$ & SSP (30) & Partial thickness $(30)$ & NR & NR \\
\hline Gibson et al., $2013^{29}$ & IV & $1(1)$ & 13 & SSC & Full thickness & $\mathrm{T}$ & American football \\
\hline Gouron et al., $2013^{30}$ & IV & $1(1)$ & 11 & SSC & Full thickness & $\mathrm{T}$ & Ice hockey \\
\hline Itoi and Tabata, $1993^{5}$ & IV & $1^{d}(1)$ & 15 & SS and IS & Partial thickness & $\mathrm{T}$ & Bicycle riding \\
\hline Muto et al., $2015^{31}$ & IV & $1(1)$ & 16 & SSC & Not reported & NT & Baseball \\
\hline Rubio et al., $2017^{32}$ & IV & $1^{e}(1)$ & 14 & SSC & Full thickness & $\mathrm{T}$ & American football \\
\hline Sanghera et al., $2010^{33}$ & IV & $1(1)$ & 14 & SSP, IS, and TM & Full thickness & $\mathrm{T}$ & Motocross \\
\hline $\begin{array}{l}\text { Schwartz and Karas, } \\
2018^{34}\end{array}$ & IV & $1(1)$ & 15 & $\mathrm{TM}$ & Full thickness & $\mathrm{T}$ & Wrestling \\
\hline Turman et al., $2010^{37}$ & IV & $1(1)$ & 16 & SSP, SSC, IS, and TM & $\begin{array}{l}\text { Full-thickness } \\
\text { supraspinatus, } \\
\text { subscapularis, and } \\
\text { infraspinatus; } \\
\text { partial-thickness } \\
\text { teres minor }\end{array}$ & $\mathrm{T}$ & American football \\
\hline Weiss et al., $2013^{38}$ & IV & $2^{\mathrm{f}}(1)$ & $15(2.83)$ & $\operatorname{SSC}(1), \operatorname{SSP}(1)$ & $\begin{array}{l}1 \text { full-thickness } \\
\text { subscapularis } \\
\text { and } 1 \text { full-thickness } \\
\text { supraspinatus }\end{array}$ & NT (2) & $\begin{array}{l}\text { Gymnastics (1), } \\
\text { basketball (1) }\end{array}$ \\
\hline $\begin{array}{l}\text { Whyte and Rokito, } \\
2016^{39}\end{array}$ & IV & $1(1)$ & 16 & SSC & Full thickness & $\mathrm{T}$ & American football \\
\hline $\begin{array}{l}\text { Zaman and Syed, } \\
2016^{40}\end{array}$ & IV & $1(0)$ & 17 & TM & Full thickness & $\mathrm{T}$ & Football (soccer) \\
\hline
\end{tabular}

IS, infraspinatus; LOE, level of evidence; NR, not reported; NT, nontraumatic; RC, rotator cuff; SD, standard deviation; SSC, subscapularis; SSP, supraspinatus; $\mathrm{T}$, traumatic; TM, teres minor.

A: Original $n=32,8$ subjects excluded due to avulsion fracture-type tears; B: Original $n=2,1$ subject excluded due to age $>18$ years; C: Original $n=53,23$ subjects excluded due to nonoperative management; D: Original $n=3,2$ subjects excluded due to age $>18$; E: Original $n=2$, 1 subject excluded due to avulsion fracture-type tear; F: Original $n=7,5$ subjects excluded due to nonoperative management (1), avulsion fracture-type tears (3), and unspecified rotator interval tear (1). 
subjects with fracture avulsion rotator cuff injuries, subjects treated nonoperatively, and/or subjects with no outcomes reported were excluded. However, studies with cohorts in which some subjects who met the above-stated inclusion criteria while others did not were included if separate outcome reporting was provided for the subjects meeting the inclusion criteria.

Selection was performed by two reviewers (N.B.C. and J.T.K.). Disagreement was resolved via consensus. Title and abstract screening were performed to exclude studies clearly not meeting eligibility criteria. Next, full text review was performed for all studies potentially meeting eligibility criteria. Covidence systematic review software was used to perform both the title and abstract and full-text reviews (Covidence, Veritas Health Innovation, Melbourne, Australia). Once full-text review was complete, variables of interest were extracted from each included study by one reviewer using an electronic spreadsheet (Google Sheets, Google LLC, Mountain View, CA). Variables extracted included level of evidence, cohort size, sex, age, physeal status, specific tendons involved, type of tear, concomitant injuries, mechanism of injury, sports played, level of baseline sports competition, physical examination findings, imaging findings, time to diagnosis, time to surgery, surgical technique, concomitant surgical procedures, length of follow up, return to play (RTP) information, patient-reported outcomes (PROs), complications, failures, and follow-up imaging findings. When variables of interest were not reported or not applicable in a given study, a place holder of "NR" or "n/a" was recorded.

\section{Methodologic Quality Assessment}

Given the rarity of this condition, it was anticipated that the literature would be composed largely of case reports and case series, which have low methodological quality and high risk of bias. As such, an adapted version of the Methodological Quality and Synthesis of Case Series and Case Reports framework proposed by Murad et al. ${ }^{19}$ was used to assess quality for all studies. The framework consists of eight yes/no questions, categorized into four domains: selection, ascertainment, causality, and reporting. An overall assessment of quality was determined for each study based on the answers to the five included questions. As described by Ramspott et al., studies were of good quality (low risk of bias) when all five questions were answered in the affirmative, moderate quality when four were affirmed, and low quality (high risk of bias) when three or fewer were affirmed. ${ }^{20}$

\section{Data Synthesis}

Given the low quality of evidence and heterogeneity in variables and outcomes reported, pooling of data and quantitative syntheses were not performed. Ranges were reported for continuous variables and simple counts for categorical variables.

\section{Results}

\section{PRISMA Search Results}

A diagram of the study identification process is available in Fig 1. The initial database search produced 3,558 results, including 1,548 duplicates, which were removed. Title and abstract screening were performed on the remaining 2,010 articles, after which 51 articles remained for full text review. Thirty-two articles were excluded on the basis of full text review, including 10 articles with cohorts of fracture avulsion rotator cuff injuries, 13 articles with adult patients, 7 articles with no outcomes reported, and 2 articles with nonoperative patient management. Two additional articles not found in the original database searches were identified via references of the articles screened for full text review. This left 21 studies published in English between 1993 and 2020 that were included for analysis., 21-40

\section{Methodologic Quality Assessment}

A full presentation of the methodologic quality assessment is available in table format in Appendix Table 2. All articles included in this review were LOE IV, except one, which was LOE III. ${ }^{28}$ Sixteen studies were retrospective case reports, four studies were retrospective case series, and one study was a retrospective cohort study that compared a cohort of subjects treated with surgical intervention to a cohort treated with nonoperative management. Only one included study was assessed to have good quality and, therefore, low risk of bias as per the Methodological Quality and Synthesis of Case Series and Case Reports framework proposed by Murad et al. ${ }^{23}$ Nine articles were assessed to have moderate quality and risk of bias, $^{24,27-29,31,32,35,37,39}$ and 11 were assessed to have low quality and, therefore, high risk of bias. $5,21,22,25,26,30,33,34,36,38,40$

\section{Patient Characteristics and Epidemiology}

The 21 included studies comprised 78 total patients. Baseline patient characteristics and injury information are presented in Table 1. The range of patient ages was 8-17 years. Fifty-seven patients were male, whereas 21 were female. Open physes were reported in 5 patients, whereas physeal status was not reported in all remaining patients. Most injuries were isolated supraspinatus tears $(n=56)$, followed by isolated subscapularis tears $(n=10)$. No other injury pattern occurred in greater than 4 patients. Sixty-nine patients experienced tears of one rotator cuff muscle alone, whereas 9 patients had injuries involving multiple rotator cuff tendons. Fifty-seven full-thickness and 22 partial-thickness tears were reported. Arm-dominance 


\begin{tabular}{|c|c|c|c|c|c|c|c|c|}
\hline Study & $\begin{array}{l}\text { Presenting } \\
\text { Complaint }\end{array}$ & $\begin{array}{c}\text { Shoulder Special Test } \\
\text { Results }\end{array}$ & Radiograph & MRI & $\begin{array}{l}\text { Time from } \\
\text { Injury to } \\
\text { Diagnosis }\end{array}$ & $\begin{array}{l}\text { Surgical } \\
\text { Approach }\end{array}$ & $\begin{array}{l}\text { Repair } \\
\text { Technique }\end{array}$ & $\begin{array}{l}\text { Concomitant } \\
\text { Procedures }\end{array}$ \\
\hline Agarwalla et al., $2020^{21}$ & $\begin{array}{l}\text { Pain, numbness, } \\
\text { tingling, } \\
\text { decreased } \\
\text { ROM }\end{array}$ & $\begin{array}{l}\text { Lift-off }(+) \\
\text { belly-press }(+)\end{array}$ & Negative & $\begin{array}{l}\text { Positive for SSC } \\
\text { tear }\end{array}$ & $<1$ month & All arthroscopic & Suture anchors & $\begin{array}{l}\text { Biceps tenodesis, SLAP } \\
\text { debridement }\end{array}$ \\
\hline Alley et al., $2016^{22}$ & $\begin{array}{l}\text { Pain, swelling, } \\
\text { decreased } \\
\text { ROM }\end{array}$ & $\begin{array}{l}\text { Testing limited due } \\
\text { to pain }\end{array}$ & Negative & $\begin{array}{l}\text { Positive for SSP } \\
\text { and IS tears }\end{array}$ & $<1$ month & $\begin{array}{l}\text { Diagnostic } \\
\text { arthroscopy } \\
\text { and open } \\
\text { repair }\end{array}$ & $\begin{array}{l}\text { Sutures through } \\
\text { transosseous } \\
\text { tunnels }\end{array}$ & Labral debridement \\
\hline Azzam et al., $2018^{23}$ & NR & NR & NR & NR & NR & $\begin{array}{l}23 \text { all } \\
\text { arthroscopic, } \\
1 \text { diagnostic } \\
\text { arthroscopy } \\
\text { and open } \\
\text { repair }\end{array}$ & $\begin{array}{l}\text { Suture anchors } \\
\quad(24)\end{array}$ & $\begin{array}{l}\text { Subacromial } \\
\text { bursectomy (24), } \\
\text { anterior labral repair } \\
\text { (8), SLAP repair (3), } \\
\text { HAGL repair (2), } \\
\text { biceps tenodesis (1), } \\
\text { rotator interval } \\
\text { closure (1), and } \\
\text { posterior capsular } \\
\text { release (1) }\end{array}$ \\
\hline Banerjee et al. $2012^{24}$ & Dislocation & $\begin{array}{l}\text { Apprehension and } \\
\text { relocation }(+)\end{array}$ & Negative & $\begin{array}{l}\text { Increased signal } \\
\text { in SSP }\end{array}$ & 9 months & All arthroscopic & Suture anchors & $\begin{array}{l}\text { Subacromial } \\
\text { bursectomy }\end{array}$ \\
\hline Battaglia et al., $2003^{25}$ & $\begin{array}{l}\text { Pain, functional } \\
\text { impairment }\end{array}$ & Impingement tests $(+)$ & Negative & $\begin{array}{l}\text { Positive for SSP } \\
\text { tear }\end{array}$ & 20 months & All arthroscopic & Soft tissue repair & $\begin{array}{l}\text { Coracoacromial } \\
\text { ligament release, } \\
\text { subacromial } \\
\text { bursectomy and } \\
\text { acromioplasty }\end{array}$ \\
\hline Bhalla et al., $2011^{26}$ & Pain, weakness & $\begin{array}{l}\text { Lift-off }(+) \text {, belly-press } \\
\qquad(+)\end{array}$ & NR & $\begin{array}{l}\text { Positive for SSC } \\
\text { tear and } \\
\text { increased SSP } \\
\text { signal }\end{array}$ & 24 months & $\begin{array}{l}\text { Diagnostic } \\
\text { arthroscopy } \\
\text { and open } \\
\text { repair }\end{array}$ & Soft tissue repair & None \\
\hline Burns et al., $2009^{27}$ & Pain (2) & $\begin{array}{l}\text { Patient } 1 \text { : } \\
\text { impingements tests, } \\
\text { active compression, } \\
\text { apprehension, and } \\
\text { crank }(+) \text {. Patient } 2 \text { : } \\
\text { NR }\end{array}$ & Negative (2) & $\begin{array}{l}\text { Positive for } \\
\text { labral tear, full } \\
\text { thickness SSP } \\
\text { tear (1); } \\
\text { Positive for } \\
\text { tear at the } \\
\text { junction of } \\
\text { SSP and ISP } \\
\text { (1) }\end{array}$ & $\begin{array}{l}6.75 \text { months } \\
\text { average } \\
\text { (range 1.5-12 } \\
\text { months) }\end{array}$ & $\begin{array}{l}\text { All arthroscopic } \\
\text { (2) }\end{array}$ & $\begin{array}{l}\text { Suture anchors } \\
\text { (2) }\end{array}$ & Labral repair (1) \\
\hline Eisner et al., $2013^{28}$ & NR & NR & NR & $\begin{array}{l}\text { Positive for } \\
\text { partial SSP } \\
\text { tears }\end{array}$ & $\begin{array}{l}5.8 \text { months } \\
\text { average } \\
\text { (range NR) }\end{array}$ & $\begin{array}{l}\text { All arthroscopic } \\
\text { (30) }\end{array}$ & $\begin{array}{l}\text { Debridement } \\
\text { only (30) }\end{array}$ & $\begin{array}{l}\text { Labral repair (number } \\
\quad \text { NR) }\end{array}$ \\
\hline Gibson et al., $2013^{29}$ & Pain, weakness & $\begin{array}{l}\text { Testing limited due to } \\
\text { pain }\end{array}$ & Negative & $\begin{array}{l}\text { Positive for } \\
\text { isolated SSC } \\
\text { tear }\end{array}$ & $<1$ month & All arthroscopic & Suture anchors & None \\
\hline
\end{tabular}




\begin{tabular}{|c|c|c|c|c|c|c|c|c|}
\hline Study & $\begin{array}{l}\text { Presenting } \\
\text { Complaint }\end{array}$ & $\begin{array}{c}\text { Shoulder Special Test } \\
\text { Results }\end{array}$ & Radiograph & MRI & $\begin{array}{l}\text { Time from } \\
\text { Injury to } \\
\text { Diagnosis }\end{array}$ & $\begin{array}{c}\text { Surgical } \\
\text { Approach }\end{array}$ & $\begin{array}{c}\text { Repair } \\
\text { Technique }\end{array}$ & $\begin{array}{l}\text { Concomitant } \\
\text { Procedures }\end{array}$ \\
\hline Gouron et al., $2013^{30}$ & Pain & Lift-off $(+)$ & Negative & $\begin{array}{l}\text { Positive for } \\
\text { isolated SSC } \\
\text { tear }\end{array}$ & $<1$ month & All open & Suture anchors & None \\
\hline Itoi and Tabata $1993^{5}$ & Pain, weakness & Impingement tests $(+)$ & $\begin{array}{l}\text { Positive for deep } \\
\text { surface tear of the } \\
\text { rotator cuff on } \\
\text { radiograph } \\
\text { arthrogram }\end{array}$ & NR & 1 month & All open & $\begin{array}{l}\text { Sutures through } \\
\text { transosseous } \\
\text { tunnels }\end{array}$ & None \\
\hline Muto et al., $2015^{31}$ & $\begin{array}{l}\text { Pain, functional } \\
\text { impairment }\end{array}$ & NR & $\begin{array}{l}\text { Positive for } \\
\text { posteroinferior } \\
\text { slipping of the } \\
\text { humeral head }\end{array}$ & $\begin{array}{l}\text { Positive for SSC } \\
\text { tendon injury, } \\
\text { also positive } \\
\text { for superior } \\
\text { glenohumeral } \\
\text { ligament and } \\
\text { middle } \\
\text { glenohumeral } \\
\text { ligament } \\
\text { lesions }\end{array}$ & NR & $\begin{array}{l}\text { Diagnostic } \\
\text { arthroscopy } \\
\text { and open } \\
\text { repair }\end{array}$ & Soft tissue repair & Rotator interval closure \\
\hline Rubio et al., $2017^{32}$ & Pain, weakness & $\begin{array}{l}\text { Lift-off }(+) \text {, belly-press } \\
(+), \text { impingement } \\
\text { tests }(-), \\
\text { apprehension tests } \\
(-)\end{array}$ & NR & $\begin{array}{l}\text { Positive for SSC } \\
\text { tear }\end{array}$ & 1.5 months & All arthroscopic & Suture anchors & None \\
\hline Sanghera et al., $2010^{33}$ & NR & $\begin{array}{l}\text { Infraspinatus, teres } \\
\text { minor, and } \\
\text { supraspinatus lag } \\
\text { signs }(+)\end{array}$ & $\begin{array}{l}\text { Positive for halo of } \\
\text { calcification superior } \\
\text { to the humeral head } \\
\text { in the subacromial } \\
\text { space }\end{array}$ & $\begin{array}{l}\text { Positive for tears } \\
\text { of the SSP, IS, } \\
\text { and TM }\end{array}$ & $<1$ month & All arthroscopic & Suture anchors & $\begin{array}{l}\text { Contralateral clavicle } \\
\text { pin fixation; } \\
\text { ipsilateral simple } \\
\text { partial bursectomy }\end{array}$ \\
\hline $\begin{array}{l}\text { Schwartz and Karas, } \\
2018^{34}\end{array}$ & Pain & NR & NR & $\begin{array}{l}\text { Positive for TM } \\
\text { tear and } \\
\text { posterior } \\
\text { HAGL lesion }\end{array}$ & $<1$ month & All arthroscopic & Suture anchors & Posterior HAGL repair \\
\hline $\begin{array}{l}\text { Smith and Funk, } \\
2012^{35}\end{array}$ & Pain & $\begin{array}{l}\text { Apprehension }(+) \text {, } \\
\text { belly-press }(+) \text {, bear } \\
\text { hug }(+)\end{array}$ & NR & $\begin{array}{l}\text { Positive for SSC } \\
\text { lesion }\end{array}$ & $<1$ month & All arthroscopic & Suture anchors & None \\
\hline Tarkin et al. $2005^{36}$ & $\begin{array}{l}\text { Pain (3), Pain } \\
\text { and transient } \\
\text { numbness (1) }\end{array}$ & $\begin{array}{l}\text { Belly-press }(+), \\
\text { impingement }(+), \\
\text { apprehension }(-)\end{array}$ & Negative (3), NR (1) & $\begin{array}{l}\text { Positive for signs } \\
\text { of rotator cuff } \\
\text { tear (3), } \\
\text { Negative (1) }\end{array}$ & $\begin{array}{l}10.5 \text { months } \\
\text { average } \\
\text { (range 3-24 } \\
\text { months) }\end{array}$ & $\begin{array}{l}\text { All open (1), all } \\
\text { arthroscopic } \\
\text { (2), diagnostic } \\
\text { arthroscopy, } \\
\text { and open } \\
\text { repair (1) }\end{array}$ & $\begin{array}{l}\text { Suture anchors } \\
\text { (1), soft tissue } \\
\text { repair (1), } \\
\text { debridement } \\
\text { only (1), NR } \\
\text { (1) }\end{array}$ & None \\
\hline
\end{tabular}




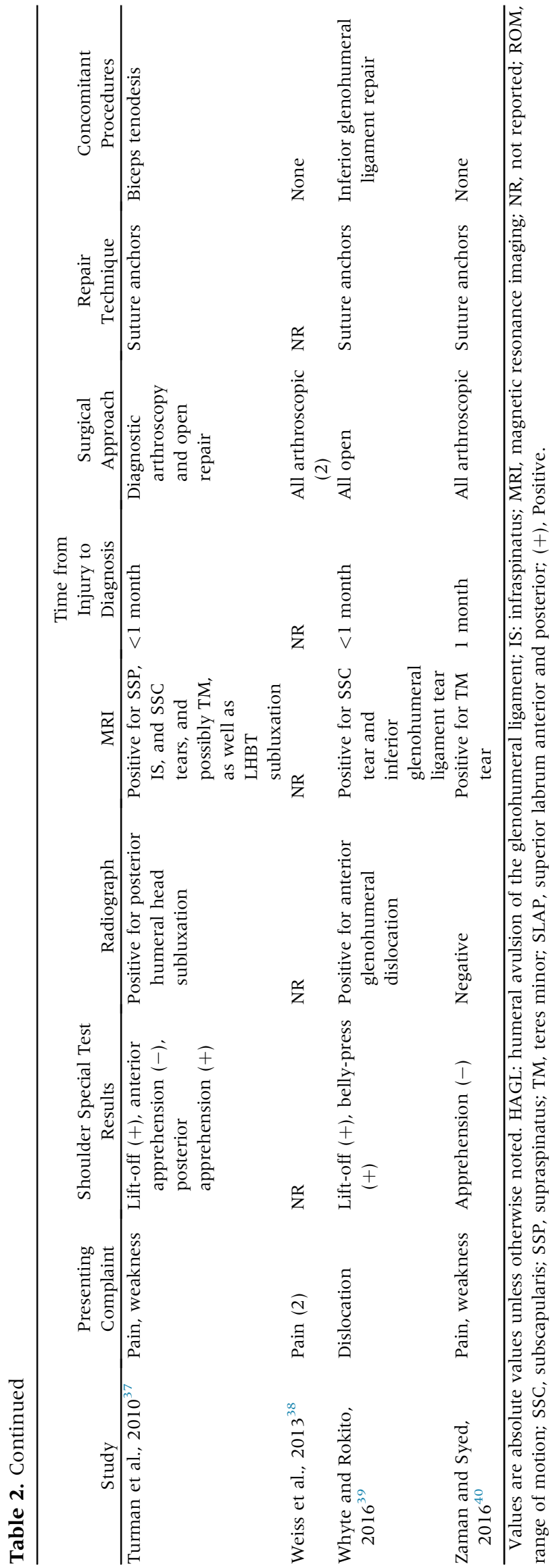

was reported in 41 patients; of these, 32 had injuries affecting the dominant arm versus 9 patients with injuries to the nondominant arm. A mechanism of injury was reported in 48 patients, and of these, 39 injuries were traumatic in nature, whereas 9 were nontraumatic. The most common inciting traumatic events were American football tackles $(n=16)$, followed by motorcycle crashes $(n=4)$ and wrestling injuries $(n=$ $4)$. The majority of nontraumatic injuries occurred in baseball players $(n=4)$ and softball players $(n=3)$. Level of baseline competition was rarely reported, although given the context, it was inferred that most included patients participated in either high school or competitive youth athletics.

\section{Clinical Examination, Imaging, and Treatment}

Presentation, evaluation, and treatment information is summarized in Table 2 . The most common presenting complaint was pain $(n=21$ out of 23 patients, for which initial presentation data was described). Others included weakness $(n=6)$, functional impairment $(n=$ $3)$, decreased range of motion (ROM) $(n=2)$, dislocation $(n=2)$, and numbness $(n=2)$. Special tests for specific rotator cuff muscle function were reported in 17 total patients. Sixteen of 17 patients had at least one positive special test that indicated rotator cuff pathology. No mention of special testing was made for the other 59 patients. In two patients, testing was limited due to pain.

Radiograph results were reported for 17 patients. Of these, 12 were reported as negative, while 5 showed signs of pathology. Of these, only two were specific to the rotator cuff. In one, an arthrogram demonstrated signs of partial rotator cuff tendon tear, ${ }^{5}$ and in another, a halo of calcification superior to the humeral head in the subacromial space indicated long-standing supraspinatus injury. ${ }^{33}$ Magnetic resonance imaging (MRI) or magnetic resonance arthrogram (MRA) results were reported for 51 patients. Of these, 50 demonstrated some indication of rotator cuff pathology, whereas only one was negative. Only 3 studies comprising 3 total patients reported ultrasound examinations. Of these, all were reported as positive for signs of rotator cuff damage. $^{30,35,40}$

The time from injury to diagnosis was reported for 51 patients and ranged from 1 day to 24 months. Fortyfive patients were diagnosed within 6 months of injury; of these, 11 were diagnosed within 1 month of injury. On the other hand, five patients were diagnosed at least one year after injury. Time from diagnosis to surgery was typically not reported, although when it was, most patients underwent surgery within 6 weeks of their diagnosis.

In 68 patients, surgery was performed in an allarthroscopic manner; in 6 patients, diagnostic arthroscopy was performed, followed by open repair, and in 
four patients, an open technique was used. The most common method of treatment involved the use of suture anchors $(n=38)$, debridement alone $(n=31)$, soft tissue only repairs $(n=4)$, and suture fixation through transosseous tunnels $(n=2)$. Repair technique was not reported for three patients. Subacromial bursectomy was the most performed concomitant procedure $(n=$ 27). Other concomitant procedures included anterior labral repairs $(n=9)$, glenohumeral ligament repairs $(n=4)$, superior labrum anterior and posterior (SLAP) repairs $(n=3)$, and biceps tenodesis $(n=3)$.

\section{Outcomes}

Treatment outcome information is summarized in Table 3. Follow-up times ranged from 5 to 74.4 months. Twenty-one patients were lost to follow up. The most reported outcomes were return to play (RTP), range of motion (ROM), and strength. Strength and ROM were described in terms of physical exam findings, and in nearly all cases, patients were reported to have regained full strength and ROM during the follow-up period. In one case, authors reported that a patient who had undergone repair of the supraspinatus and infraspinatus had a persistent strength deficit of $4 / 5$ on manual testing of resisted external rotation at one-year followup. ${ }^{5}$

Return to play outcomes were reported in 15 of the included studies encompassing 51 patients. Of these, 46 returned to sport within the described follow-up periods. The time to RTP was reported in 11 studies encompassing 15 patients with a range of 2.5 to 12 months from surgery to RTP. Most studies either did not report the level of RTP or indicated that patients returned to the same level of play without mention of return to preinjury function. One study reported patients' subjective evaluations of their performance compared to their preinjury baseline and found that $37 \%$ reported that they were better, $37 \%$ reported that they were the same, and $26 \%$ reported that they were worse. $^{23}$ One baseball player was unable to return to baseball during the follow-up period but did return to play basketball and other sports (level of play not reported). ${ }^{36}$

Azzam et al. reported American Shoulder and Elbow Surgeons Shoulder Assessment Form scores (mean: 93, SD: 9), Western Ontario Rotator Cuff Index scores (mean: 89\%, SD: 13\%), and Numeric Pain Scale scores (mean 0.3, SD: 0.8 ) for the patients in their cohort. ${ }^{23}$ Eisner et al. reported Single Assessment Numeric Evaluation scores (mean: 80.6, SD: 17.1), QuickDASH (Disability of the Arm, Shoulder, and Hand) scores (mean: 8.1, SD: 11.1), and QuickDASH sports module scores (mean: 19.5, SD: 24.3) for their cohort. ${ }^{28}$ Other PROs found among the included studies were the Oxford Shoulder Score assessed for one patient (score: 50), ${ }^{22}$ the Constant and Rowe questionnaires for another patient (scores $=97$ and 96, respectively), ${ }^{24}$ and Subjective Shoulder Value score for another patient $($ score $=95 \%) .{ }^{32}$

No perioperative or early postoperative surgical complications were reported. Three treatment failures were reported among all included studies. Two failures were described in the study by Azzam et al., who reported one patient with a shoulder dislocation 41 months postoperatively who required labral and infraspinatus repair and one patient with symptomatic pain at 40 months postoperatively who was found to have partial retear and required rotator cuff debridement. ${ }^{23}$ Weiss et al. reported that one patient experienced retear of the repaired tendon 11 months postoperatively, but no subsequent treatment details were provided. ${ }^{38}$ Although not considered a treatment failure, in the study by Tarkin et al., a single patient returned to clinic two years postoperatively with shoulder "clicking," but elected not to pursue any treatment as he had full function. ${ }^{36}$

Two studies reported follow-up imaging. Tarkin et al. reported that one patient underwent a radiograph 2 years after surgery because of subjective "clicking" in the shoulder. He was found to have evidence of heterotopic ossification but declined further treatment because the symptoms were not causing pain or functional impairment. Turman et al. reported that an MRI was performed 3 months postoperatively for a patient because he was in a car crash during the follow-up period and reported an increase in shoulder symptoms. The MRI demonstrated no evidence of retear. ${ }^{37}$

\section{Discussion}

The findings of this review show that tendinous rotator cuff tears in pediatric patients occur infrequently. Male collision sport athletes are most commonly affected, although female athletes and those who participate in throwing sports are also at risk. The supraspinatus was the most affected tendon. While radiographs were almost universally negative, reported rotator cuff special tests were almost always positive. As expected, MRI was very accurate, with an ability to detect the presence of a tear in all but one of the patients included in this review. Early utilization of MRI should be considered when the clinical presentation is concerning for rotator cuff involvement. These injuries were most often addressed via arthroscopic repair with suture anchors. An important finding of this study is that following surgical intervention, 46 of 51 patients for whom data were available were able to return to sport within a range of 2.5 to 12 months postoperatively. These findings may provide clinicians with valuable information when counselling pediatric athletes regarding the expected outcomes of rotator cuff surgery. Furthermore, 
Table 3. Treatment Outcomes

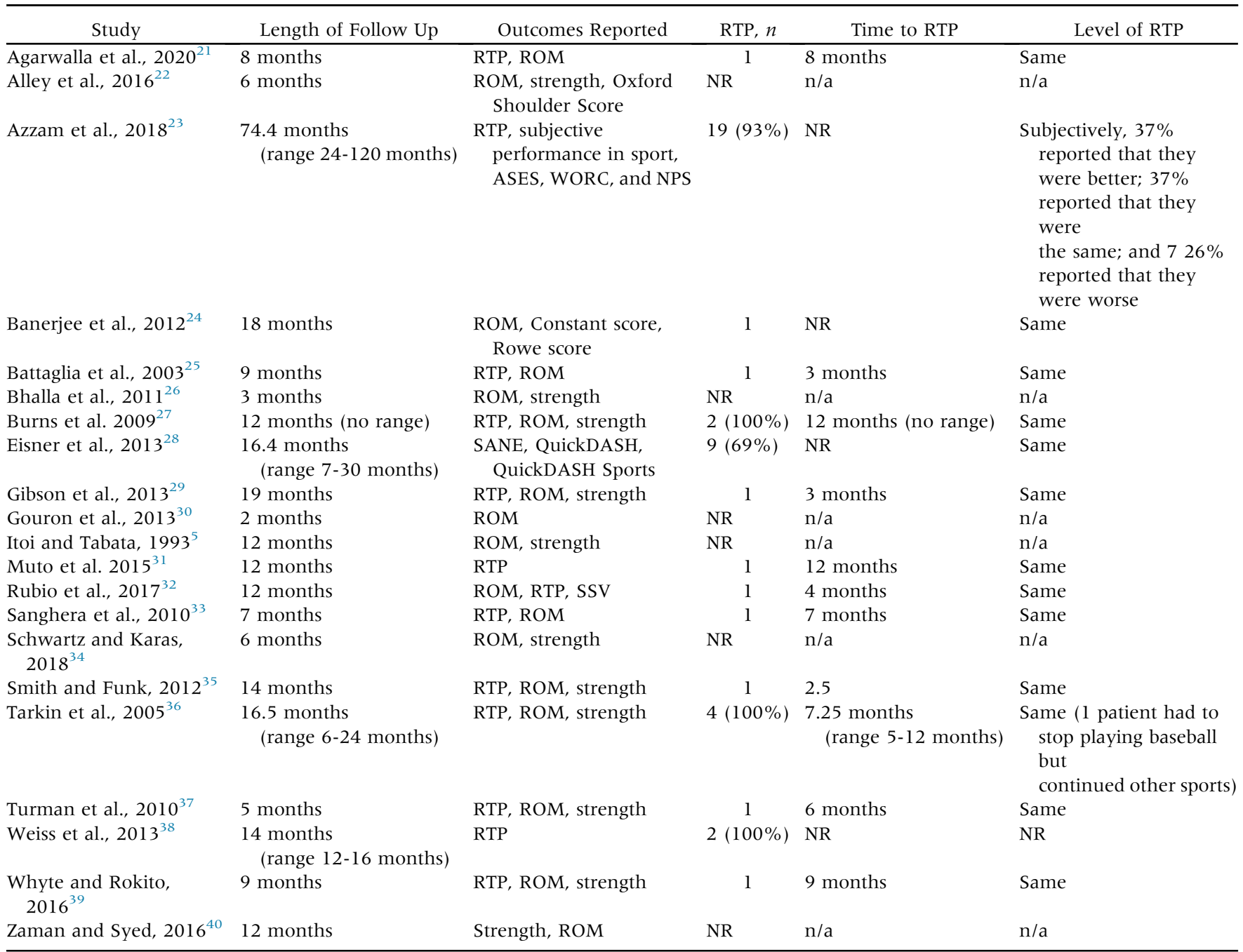

ASES, American Shoulder and Elbow Surgeons Shoulder Assessment Form; n/a, not applicable; NPS, Numeric Pain Scale; NR, not reported; PROs, patient-reported outcome measures; ROM, range of motion; RTP, return to play; SANE, Single Assessment Numeric Evaluation; SSV, Subjective Shoulder Value; WORC, Western Ontario Rotator Cuff Index.

treatment failures occurred in only 3 patients, indicating that surgical management is likely safe and efficacious. These findings confirmed our hypothesis that pediatric patients who underwent surgery for a torn rotator cuff tendon would display excellent outcomes and a successful ability to return to full activity following surgical intervention.

In a similar systematic review of subscapularis avulsion injuries in 60 skeletally immature patients, Vavken et al. included both operatively and nonoperatively managed patients. ${ }^{14}$ In their pooled cohort, clinical examination was moderately sensitive in elucidating subscapularis pathology. Subscapularis strength was assessed in 45 of the 60 patients, and weakness was noted in 39 cases. Increased passive external rotation compared to the contralateral arm was noted in $62 \%$ of patients. Conversely, we found that rotator cuff special tests were positive in 16 out of 17 patients for whom this was reported within our pooled cohort. Somewhat surprisingly, only 7 of 43 patients who underwent radiograph imaging had findings consistent with an avulsion injury ( $16 \%$ sensitivity) in the study by Vavken et al., whereas the sensitivity of advanced imaging was superior (95\% sensitivity for MRI). ${ }^{14}$ These findings were in concert with the imaging findings in our study and demonstrate the challenge of diagnosis without advanced imaging. This is especially important in a pediatric population where rotator cuff tears are not a part of the initial differential diagnoses, and therefore, advanced imaging may not be ordered. The findings of both reviews demonstrate that if pediatric patients have rotator cuff symptoms, clinicians should have an index of suspicion for possible tendon pathology, regardless of radiologic findings. 
The RTP findings of our study are similar to those recently reported by Davey et al., who published a study examining clinical outcomes for 20 patients aged 18 to 29 years after arthroscopic rotator cuff repair. ${ }^{11}$ They found an overall RTP of $85 \%$ in their series, which included 2 professional athletes, 16 competitive athletes, and 2 recreational athletes. As in our study, the majority of patients were male collision sport athletes. The baseline level of competition for athletes who sustain rotator cuff injuries may influence the rate of return to sport. This notion is supported by the findings of Lazarides et al., who found that while outcomes of rotator cuff repair in younger patients $(<40$ years) were favorable in most cases, competitive-level throwing athletes had poor return to sport rates (range 25$97 \%) .{ }^{41}$ Similarly, Klouche et al., in a systematic review of RTP following rotator cuff repair, found an overall return to sport of $85 \%$ versus only $50 \%$ in the professional and competitive athlete subgroup. ${ }^{42}$

Because most of the studies included in our review did not report level of return to play, it is difficult to assess the true efficacy of rotator cuff repair with regard to high-level youth athletes. High-level youth athletes (and their parents and coaches) often measure athletic success in terms of matriculation to the next level of competition, e.g., securing a collegiate scholarship or placing in a competitive academy-level program. ${ }^{43}$ Only one of the studies included in our analysis specifically reported on this criterion. Azzam et al. found that $30 \%$ of athletes in their case series went on to play intercollegiate athletics. ${ }^{23}$ Surprisingly, this is higher than the national average rate of progression to varsity college athletics for high school athletes, which ranges from $3.5 \%$ (men's basketball) to $26.2 \%$ (women's ice hockey). ${ }^{44}$ Of course, many variables apart from injury status contribute to an athlete's ability to progress to the next level, so it is not known how the rotator cuff injury and repair specifically factored into these findings.

Another explanation for the excellent RTP and low complication rates found in our review is that skeletally immature patients may have a better biological environment at the repair site and, therefore, an improved ability to heal following musculoskeletal injuries compared to adults. ${ }^{45,46}$ This improved healing biology in pediatric musculoskeletal tissues has been demonstrated in ligamentous, ${ }^{47}$ as well as tendinous tissues. ${ }^{48,49}$ Perhaps, given the regenerative potential of juvenile connective tissues, patients with these injuries may exhibit similar results when managed nonoperatively. In one case report of a 9-year-old boy with a massive intrasubstance rotator cuff tear, a nonoperative treatment regimen using a custom-fit brace resulted in return to the same level of baseball and basketball within 1 year of injury. ${ }^{50}$ It is unknown whether the same positive results could be expected in older youth athletes, such as high schoolers looking to secure collegiate scholarships. Eisner et al. found that for youth athletes with partial-thickness rotator cuff tears, nonoperative outcomes were comparable to operative outcomes. ${ }^{28}$ Readers should exercise caution when interpreting the generalizability of these results however, as it is known that partial-thickness rotator cuff tears follow a distinct natural history of recovery when compared to full-thickness tears. ${ }^{51}$

Another interesting finding in our review was that outcomes were excellent whether surgery was performed within 1 month of injury or delayed by up to 2 years. This finding contradicts the classic approach that early operative intervention is important for traumatic tears to avoid atrophy and scar tissue formation, which may increase the failure rate of surgical repair. ${ }^{15,52}$ However, more than just biology must be considered when deciding on the timing of treatment for rotator cuff injuries in pediatric patients. While patients who underwent late repair did experience excellent outcomes, they were either limited or unable to participate in sporting activities while awaiting proper diagnosis and treatment of their injuries. Such time away from sport is problematic, given the physical, social, and psychological benefits of sport participation for children and adolescents. ${ }^{53-56}$ Although pediatric patients have superior biological capacity for healing and satisfactory outcomes with delayed treatment, these factors cannot exclusively guide treatment algorithms. Early diagnosis and initiation of treatment has the potential added benefit of limiting complications or concomitant injuries that may develop as a result of the rotator cuff tear, as well as minimizing the duration of pain and/or functional and social limitation. While sports medicine physicians will infrequently encounter rotator cuff injuries in the pediatric population, this review will serve as a valuable reference for managing these rare patients.

The final takeaway of this review is that the current literature investigating rotator cuff injuries in the pediatric population is limited and of poor quality. Of the 21 studies included in this review, 20 were classified as LOE IV. Only one studied compared outcomes of patients treated surgically to patients treated nonsurgically and was, thus, classified as LOE III. ${ }^{28}$ Additionally, only one study was determined to be of high quality and with a low risk of bias as per the methodology outlined by Ramspott et al. ${ }^{20,23}$ The combination of low-quality reporting, risk of bias, and heterogeneity restricted our ability to pool data for quantitative syntheses. Further prospective, high-quality evidence is needed to determine the natural history of rotator cuff tendon tears in pediatric patients and to evaluate the long-term outcomes of operative versus nonoperative management. Multi-institutional studies are also likely necessary to ensure methodological rigor, given the rarity of the condition. 


\section{Limitations}

This study has several limitations. First and foremost, it includes evidence abstracted from case reports and small case series with high risk of bias. Conclusions drawn from pooling low-quality data may result in misinterpretation and unfounded conclusions. ${ }^{57}$ Because of these limitations, no pooling of data was undertaken in our systematic review, and conclusions are appropriately limited to general observations gleaned from our qualitative review. Another limitation of this review is only including surgically treated patients. No comparisons can be drawn about surgical versus nonsurgical treatment, which would be useful information for clinicians. Another important limitation of this study is the unknown physeal status of most patients in this cohort. Once a patient is skeletally mature, regardless of whether they are under the age of 18, many orthopedic surgeons consider these patients to be physiological "adults" when it comes to treatment of their musculoskeletal conditions.

\section{Conclusion}

The extant literature regarding rotator cuff tears in pediatric patients is limited to reports of low methodological quality. Qualitative synthesis of this low-level literature reveals that rotator cuff tears are mostly reported in male collision sport athletes, but they may also occur in female athletes and/or throwing athletes. These injuries are often successfully managed via arthroscopic repair and patients and their families can be reassured that the majority of patients return to sports following surgery.

\section{References}

1. Yamamoto A, Takagishi K, Osawa T, et al. Prevalence and risk factors of a rotator cuff tear in the general population. J. Shoulder Elbow Surg 2010;19:116-120.

2. Milgrom C, Schaffler M, Gilbert S, van Holsbeeck M. Rotator-cuff changes in asymptomatic adults. The effect of age, hand dominance and gender. J Bone Joint Surg $\mathrm{Br}$ 1995; 77:296-298.

3. Sørensen AKB, Bak K, Krarup AL, et al. Acute rotator cuff tear. Do we miss the early diagnosis? A prospective study showing a high incidence of rotator cuff tears after shoulder trauma. J. Shoulder Elbow Surg 2007;16:174- 180.

4. Mall NA, Lee AS, Chahal J, et al. An evidenced-based examination of the epidemiology and outcomes of traumatic rotator cuff tears. Arthroscopy 2013;29:366-376.

5. Itoi E, Tabata S. Rotator cuff tears in the adolescent. Orthopedics 1993;16:78-81.

6. Norwood LA, Barrack R, Jacobson KE. Clinical presentation of complete tears of the rotator cuff. J Bone Joint Surg Am 1989;71:499-505.

7. Moyer JE, Brey JM. Shoulder injuries in pediatric athletes. Orthop Clin North Am 2016;47:749-762.

8. Carson WG Jr, Gasser SI. Little Leaguer's shoulder. A report of 23 cases. Am J Sports Med 1998;26:575-580.
9. Laprade RF, Agel J, Baker J, et al. AOSSM early sport specialization consensus statement. Orthop J Sports Med 2016;4:232596711664424.

10. Bell DR, Post EG, Trigsted SM, Hetzel S, McGuine TA, Brooks MA. Prevalence of sport specialization in high school athletics. Am J Sports Med 2016;44:1469-1474.

11. Davey MS, Hurley ET, Scanlon JP, Gaafar M, Pauzenberger L, Mullett H. Excellent clinical outcomes and rates of return to play after arthroscopic rotator cuff repair for traumatic tears in athletes aged 30 years or less. Arthrosc Sports Med Rehabil 2021;3:e667-e672.

12. Kleposki RW, Wells L, Wilson M, Sehgal K. Rotator cuff injuries in skeletally immature patients: Prevention and indications for the orthopaedic nurse. Orthop Nurs 2009;28:134-138. quiz 139-140.

13. Perez JR, Massel D, Barrera CM, et al. Rotator cuff tears in the pediatric population: Comparing findings on arthroscopic evaluation to pre-operative magnetic resonance imaging. J Clin Orthop Trauma 2018;9:S123-S128.

14. Vavken P, Bae DS, Waters PM, Flutie B, Kramer DE. Treating subscapularis and lesser tuberosity avulsion injuries in skeletally immature patients: A systematic review. Arthroscopy 2016;32:919-928.

15. Browning DG, Desai MM. Rotator cuff injuries and treatment. Primary Care: Clinics in Office Practice 2004;31: 807-829.

16. Grimshaw CS, Cannada LK, Cutuk A, Kaar SG. Missed rotator cuff tears in polytraumatized patients. Am J Orthop (Belle Mead NJ) 2013;42:466-469.

17. Smith AM. Psychological impact of injuries in athletes. Sports Med 1996;22:391-405.

18. Harris JD, Quatman CE, Manring MM, Siston RA, Flanigan DC. How to write a systematic review. Am J Sports Med 2014;42:2761-2768.

19. Murad MH, Sultan S, Haffar S, Bazerbachi F. Methodological quality and synthesis of case series and case reports. BMJ Evid-Based Med 2018;23:60-63.

20. Ramspott JP, Jäger T, Lechner M, et al. A systematic review on diagnostics and surgical treatment of adult rightsided Bochdalek hernias and presentation of the current management pathway. Hernia In press. 10.1007/s10029021-02445-1.

21. Agarwalla A, Puzzitiello RN, Leong NL, Allison B, Romeo AA, Forsythe B. Primary arthroscopic repair of a traumatic isolated subscapularis tendon rupture in an adolescent patient. Orthopedics 2020;43:e182-el86.

22. Alley MC, Banerjee S, Papaliodis D, Tsitos K, Zanaros GS. Transosseous physeal-sparing rotator cuff repair in an adolescent football player. Orthopedics 2016;39: e353-358.

23. Azzam MG, Dugas JR, Andrews JR, Goldstein SR, Emblom BA, Cain EL. Rotator cuff repair in adolescent athletes. Am J Sports Med 2018;46:1084-1090.

24. Banerjee M, Bouillon B, Helm P, Akoto R, Balke M, Shafizadeh S. Recurrent anterior shoulder dislocation due to a partial-thickness articular surface supraspinatus tendon tear without capsulolabral lesion. J Shoulder Elbow Surg 2012;21:e6-e9.

25. Battaglia TC, Barr MA, Diduch DR. Rotator cuff tear in a 13-year-old baseball player: A case report. Am J Sports Med 2003;31:779-782. 
26. Bhalla A, Higashigawa K, McAllister D. Subscapularis tendon rupture in an 8-year-old boy: a case report. Am J Orthop (Belle Mead NJ) 2011;40:471-474.

27. Burns TC, Reineck JR, Krishnan SG. Rotator cuff tears in adolescent female catchers. J Shoulder Elbow Surg 2009; 18: e13-16.

28. Eisner EA, Roocroft JH, Moor MA, Edmonds EW. Partial rotator cuff tears in adolescents: Factors affecting outcomes. J Pediatr Orthop 2013;33:2-7.

29. Gibson ME, Gurley D, Trenhaile S. Traumatic subscapularis tendon tear in an adolescent American football player. Sports Health 2013;5:267-269.

30. Gouron R, Deroussen F, Juvet-Segarra M, Mancheron C, Bonnaire B, Collet LM. Isolated rupture of the subscapularis tendon in children: A case report and literature review. J Pediatr Orthop B 2013;22:138-140.

31. Muto T, Ninomiya $H$, Inui $H$, Komai $M$, Nobuhara K. Rotator interval lesion and damaged subscapularis tendon repair in a high school baseball player. Case Rep Orthop 2015;2015:1-4.

32. Rubio DR, Piposar J, Blaine T, Sutton KM. Arthroscopic repair of isolated pediatric subscapularis tears. Annals Sports Med Res 2017;4:1107.

33. Sanghera NS, Funk L. Arthroscopic repair of a traumatic massive posterior rotator cuff tear in a 14-year-old teenager. Shoulder Elbow 2010;2:185-187.

34. Schwartz A, Karas S. Arthroscopic repair of an isolated teres minor tear with associated posterior glenohumeral ligament avulsion. JSES Open Access 2018;2:133-136.

35. Smith EK, Funk L. Isolated subscapularis rupture in an adolescent-Arthroscopic repair and outcome-Case study. Injury Extra 2012;43:60-62.

36. Tarkin IS, Morganti CM, Zillmer DA, McFarland EG, Giangarra CE. Rotator cuff tears in adolescent athletes. Am J Sports Med 2005;33:596-601.

37. Turman KA, Anderson MW, Miller MD. Massive rotator cuff tear in an adolescent athlete: A case report. Sports Health 2010;2:51-55.

38. Weiss JM, Arkader A, Wells LM, Ganley TJ. Rotator cuff injuries in adolescent athletes. J Pediatr Orthop B 2013;22: 133-137.

39. Whyte G, Rokito A. The teenage terrible triad: A case report. Bull Hosp Jt Dis (2013) 2016;74:172-175.

40. Zaman SU, Syed HM. Arthroscopic repair of an isolated teres minor tear: A case report. JBJS Case Connect 2016;6: e40.

41. Lazarides AL, Alentorn-Geli E, Choi JHJ, et al. Rotator cuff tears in young patients: A different disease than rotator cuff tears in elderly patients. J Shoulder Elbow Surg 2015;24:1834-1843.

42. Klouche S, Lefevre N, Herman S, Gerometta A, Bohu Y. Return to sport after rotator cuff tear repair. Am J Sports Med 2016;44:1877-1887.
43. Difiori JP, Benjamin HJ, Brenner JS, et al. Overuse injuries and burnout in youth sports: A position statement from the American Medical Society for Sports Medicine. Br J Sports Med 2014;48:287-288.

44. National Collegiate Athletic Association. Estimated probability of competing in college athletics, https://www. ncaa.org/about/resources/research/estimated-probabilitycompeting-college-athletics. Accessed August 1, 2021.

45. Soprano JV. Musculoskeletal injuries in the pediatric and adolescent athlete. Curr Sports Med Rep 2005;4:329-334.

46. Norrby K, Bergström S, Druvefors P. Age-dependent mitogenesis in normal connective tissue cells. Virchows Arch B Cell Pathol Incl Mol Pathol 1981;36:27-34.

47. Mastrangelo AN, Magarian EM, Palmer MP, Vavken P, Murray MM. The effect of skeletal maturity on the regenerative function of intrinsic ACL cells. J Orthop Res 2010;28:644-651.

48. Howell K, Chien C, Bell R, et al. Novel model of tendon regeneration reveals distinct cell mechanisms underlying regenerative and fibrotic tendon healing. Sci Rep 2017;7: 45238 .

49. Ippolito E, Natali PG, Postacchini F, Accinni L, De Martino C. Morphological, immunochemical, and biochemical study of rabbit achilles tendon at various ages. J Bone Joint Surg Am 1980;62:583-598.

50. Lewis MK, Ramos-Williams O, Syed HM, Gregorius TK. A novel treatment for a rare injury: Pediatric massive intrasubstance rotator cuff and periscapular muscle tears treated with a custom brace: A case report. JBJS Case Connect 2018;8:e14.

51. Matthewson G, Beach CJ, Nelson AA, et al. Partial thickness rotator cuff tears: current concepts. Adv Orthop 2015;2015:1-11.

52. Lin YP, Huang TF, Hung SC, Ma HL, Liu CL. Rotator cuff tears in patients younger than 50 years of age. Acta Orthop Belg 2012;78:592-596.

53. Gagliardi AG, Walker GA, Dahab KS, et al. Sports participation volume and psychosocial outcomes among healthy high school athletes. J Clin Transl Res 2020;6: 54-60.

54. Howell DR, Kirkwood MW, Laker S, Wilson JC. Collision and contact sport participation and quality of life among adolescent athletes. J Athlet Train 2020;55:1174-1180.

55. Merkel D. Youth sport: Positive and negative impact on young athletes. Open Access J Sports Med 2013:151.

56. Taliaferro LA, Rienzo BA, Miller MD, Pigg RM, Dodd VJ. High school youth and suicide risk: Exploring protection afforded through physical activity and sport participation. J School Health 2008;78:545-553.

57. Cote MP, Lubowitz JH, Rossi MJ, Brand JC. Reviews pooling heterogeneous, low-evidence, high-bias data result in incorrect conclusions: But heterogeneity is an opportunity to explore. Arthroscopy 2018;34:3126-3128. 
Appendix Table 1. Search strategy

\begin{tabular}{|c|c|c|c|}
\hline Database & Query Date & Search String & Results \\
\hline PubMed & 15 Mar 2021 & $\begin{array}{l}\text { "Pediatrics"[Mesh] OR "Child"[Mesh] OR "Adolescent"[Mesh] OR pediatric*[tiab] OR paediatric*} \\
\text { [tiab] OR child*[tiab] OR kid[tiab] OR kids[tiab] OR adolescen*[tiab] OR teen*[tiab] OR preteen* } \\
\text { [tiab] OR "pre-teen"[tiab] OR "pre-teens"[tiab] OR pubescen*[tiab] OR prepubescen*[tiab] OR "pre- } \\
\text { pubescent"[tiab] OR "pre-pubescents"[tiab] OR "pre-pubescence"[tiab] OR juvenile*[tiab] OR } \\
\text { youth*[tiab] OR "high school"[tiab]) AND ("Rotator Cuff Injuries"[Mesh] OR "Rotator Cuff"[Mesh] } \\
\text { OR "rotator cuff" [tiab] OR "rotator cuffs"[tiab] OR supraspinatus[tiab] OR infraspinatus[tiab] OR } \\
\text { subscapularis[tiab] OR "teres minor"[tiab]) AND (english[Filter]) }\end{array}$ & 1319 \\
\hline Scopus & 15 Mar 2021 & $\begin{array}{l}\text { TITLE-ABS-KEY (pediatric* OR paediatric* OR child* OR kid OR kids OR adolescen* OR teen* OR } \\
\text { preteen* OR "pre-teen" OR "pre-teens" OR pubescen* OR prepubescen* OR "pre-pubescent" OR } \\
\text { "pre-pubescents" OR "pre-pubescence" OR juvenile* OR youth* OR "high school") AND TITLE-ABS- } \\
\text { KEY("rotator cuff" OR "rotator cuffs" OR supraspinatus OR infraspinatus OR subscapularis OR "teres } \\
\text { minor") AND (LIMIT-TO(LANGUAGE, "English") }\end{array}$ & 1661 \\
\hline
\end{tabular}

Mesh, Medical subject headings; tiab, Title and abstract; CINAHL, Cumulative Index to Nursing and Allied Health Literature; MH, major and minor headings; ABS, abstract. 
Appendix Table 2. Methodological Quality Assessment Table

\begin{tabular}{|c|c|c|c|c|c|c|c|c|c|}
\hline \multirow[b]{2}{*}{$\overline{\text { Study }}$} & \multirow[b]{2}{*}{$\begin{array}{l}\text { Selection } \\
\text { 1. Does the patient(s) } \\
\text { represent(s) the } \\
\text { whole experience } \\
\text { of the investigator } \\
\text { or is the selection } \\
\text { method unclear } \\
\text { to the extent that } \\
\text { other patients with } \\
\text { similar presentation } \\
\text { may not have } \\
\text { been reported? }\end{array}$} & \multicolumn{2}{|c|}{ Ascertainment } & \multirow[b]{2}{*}{$\begin{array}{l}\text { 4. Were other } \\
\text { alternative } \\
\text { causes that } \\
\text { may explain } \\
\text { the observation } \\
\text { ruled out? }\end{array}$} & \multicolumn{2}{|c|}{ Causality } & \multirow[b]{2}{*}{$\begin{array}{l}\text { 7. Was follow-up } \\
\text { long enough } \\
\text { for outcomes } \\
\text { to occur? }\end{array}$} & \multirow[b]{2}{*}{$\begin{array}{c}\text { Reporting } \\
\text { 8. Is the } \\
\text { case }(\mathrm{s}) \\
\text { described } \\
\text { with sufficient } \\
\text { details to } \\
\text { allow other } \\
\text { investigators } \\
\text { to replicate } \\
\text { the research } \\
\text { or to allow } \\
\text { practitioners } \\
\text { make inferences } \\
\text { related to their } \\
\text { own practice? }\end{array}$} & \multirow[b]{2}{*}{$\begin{array}{c}\text { Overall } \\
\text { Quality } \\
\text { Assessment }\end{array}$} \\
\hline & & $\begin{array}{l}\text { 2. Was the } \\
\text { exposure } \\
\text { adequately } \\
\text { ascertained? }\end{array}$ & $\begin{array}{l}\text { 3. Was the } \\
\text { outcome } \\
\text { adequately } \\
\text { ascertained? }\end{array}$ & & $\begin{array}{l}\text { 5. Was there } \\
\text { a challenge/ } \\
\text { rechallenge } \\
\text { phenomenon? }\end{array}$ & $\begin{array}{c}\text { 6. Was there a } \\
\text { dose-response } \\
\text { effect? }\end{array}$ & & & \\
\hline $\begin{array}{l}\text { Agarwalla et al., } \\
2020^{21}\end{array}$ & no & yes & yes & $\mathrm{n} / \mathrm{a}$ & $\mathrm{n} / \mathrm{a}$ & $\mathrm{n} / \mathrm{a}$ & no & yes & Low \\
\hline Alley et al., $2016^{22}$ & no & yes & yes & $\mathrm{n} / \mathrm{a}$ & $\mathrm{n} / \mathrm{a}$ & $\mathrm{n} / \mathrm{a}$ & no & yes & Low \\
\hline Azzam et al. $2018^{23}$ & yes & yes & yes & $\mathrm{n} / \mathrm{a}$ & $\mathrm{n} / \mathrm{a}$ & $\mathrm{n} / \mathrm{a}$ & yes & yes & Good \\
\hline $\begin{array}{l}\text { Banerjee et al., } \\
2012^{24}\end{array}$ & no & yes & yes & $\mathrm{n} / \mathrm{a}$ & $\mathrm{n} / \mathrm{a}$ & $\mathrm{n} / \mathrm{a}$ & yes & yes & Moderate \\
\hline Battaglia et al., $2003^{25}$ & no & yes & yes & $\mathrm{n} / \mathrm{a}$ & $\mathrm{n} / \mathrm{a}$ & $\mathrm{n} / \mathrm{a}$ & no & yes & Low \\
\hline Bhalla et al., $2011^{26}$ & no & yes & no & $\mathrm{n} / \mathrm{a}$ & $\mathrm{n} / \mathrm{a}$ & $\mathrm{n} / \mathrm{a}$ & no & yes & Low \\
\hline Burns et al., $2009^{27}$ & no & yes & yes & $\mathrm{n} / \mathrm{a}$ & $\mathrm{n} / \mathrm{a}$ & $\mathrm{n} / \mathrm{a}$ & yes & yes & Moderate \\
\hline Eisner et al., $2013^{28}$ & yes & yes & no & $\mathrm{n} / \mathrm{a}$ & $\mathrm{n} / \mathrm{a}$ & $\mathrm{n} / \mathrm{a}$ & yes & yes & Moderate \\
\hline Gibson et al. $2013^{29}$ & no & yes & yes & $\mathrm{n} / \mathrm{a}$ & $\mathrm{n} / \mathrm{a}$ & $\mathrm{n} / \mathrm{a}$ & yes & yes & Moderate \\
\hline Gouron et al., $2013^{30}$ & no & yes & no & $\mathrm{n} / \mathrm{a}$ & $\mathrm{n} / \mathrm{a}$ & $\mathrm{n} / \mathrm{a}$ & no & yes & Low \\
\hline Itoi and Tabata, $1993^{5}$ & yes & yes & no & $\mathrm{n} / \mathrm{a}$ & $\mathrm{n} / \mathrm{a}$ & $\mathrm{n} / \mathrm{a}$ & no & yes & Low \\
\hline Muto et al., $2015^{31}$ & no & yes & yes & $\mathrm{n} / \mathrm{a}$ & $\mathrm{n} / \mathrm{a}$ & $\mathrm{n} / \mathrm{a}$ & yes & yes & Moderate \\
\hline Rubio et al. $2017^{32}$ & no & yes & yes & $\mathrm{n} / \mathrm{a}$ & $\mathrm{n} / \mathrm{a}$ & $\mathrm{n} / \mathrm{a}$ & yes & yes & Moderate \\
\hline $\begin{array}{l}\text { Sanghera et al., } \\
2010^{33}\end{array}$ & no & yes & no & $\mathrm{n} / \mathrm{a}$ & $\mathrm{n} / \mathrm{a}$ & $\mathrm{n} / \mathrm{a}$ & no & yes & Low \\
\hline $\begin{array}{l}\text { Schwartz and Karas, } \\
2018^{34}\end{array}$ & no & yes & no & $\mathrm{n} / \mathrm{a}$ & $\mathrm{n} / \mathrm{a}$ & $\mathrm{n} / \mathrm{a}$ & no & yes & Low \\
\hline $\begin{array}{l}\text { Smith and Funk, } \\
2012^{35}\end{array}$ & no & yes & yes & $\mathrm{n} / \mathrm{a}$ & $\mathrm{n} / \mathrm{a}$ & $\mathrm{n} / \mathrm{a}$ & yes & yes & Moderate \\
\hline Tarkin et al., $2005^{36}$ & no & yes & yes & $\mathrm{n} / \mathrm{a}$ & $\mathrm{n} / \mathrm{a}$ & $\mathrm{n} / \mathrm{a}$ & yes & no & Low \\
\hline Turman et al. $2010^{37}$ & no & yes & yes & $\mathrm{n} / \mathrm{a}$ & $\mathrm{n} / \mathrm{a}$ & $\mathrm{n} / \mathrm{a}$ & yes & yes & Moderate \\
\hline Weiss et al., $2013^{38}$ & yes & yes & no & $\mathrm{n} / \mathrm{a}$ & $\mathrm{n} / \mathrm{a}$ & $\mathrm{n} / \mathrm{a}$ & yes & no & Low \\
\hline $\begin{array}{l}\text { Whyte and Rokito, } \\
2016^{39}\end{array}$ & no & yes & yes & $\mathrm{n} / \mathrm{a}$ & $\mathrm{n} / \mathrm{a}$ & $\mathrm{n} / \mathrm{a}$ & no & yes & Moderate \\
\hline $\begin{array}{l}\text { Zaman and Syed } \\
\qquad 2016^{40}\end{array}$ & no & yes & no & $\mathrm{n} / \mathrm{a}$ & $\mathrm{n} / \mathrm{a}$ & $\mathrm{n} / \mathrm{a}$ & yes & yes & Low \\
\hline
\end{tabular}

